\title{
www.czasopisma.pan.pl \\ Effect of the Annealing Temperature on the Microstructure and Properties of Ausferritic Nodular Cast Iron
}

\author{
G. Gumienny *, L. Klimek, B. Kurowska \\ Department of Materials Engineering and Production Systems \\ Department of Materials Engineering and Production Systems, Lodz University of Technology, \\ Stefanowskiego 1/15 Street, 90-924 Łódź, Poland
}

Received 22.03.2016; accepted in revised form 04.05.2016

\begin{abstract}
The paper presents the microstructure and selected properties of ausferritic nodular cast iron annealed at the temperature 520 and $550^{\circ} \mathrm{C}$. This choice was dictated by the temperatures used in the practice of nitriding. Nodular graphite in cast iron was obtained with use of Inmold process. Cast iron containing molybdenum and copper ensuring obtaining an ausferrite in the cast iron matrix without the use of heat treatment of castings was tested. The effect of annealing temperature on the microstructure and the kind of fracture of the ausferritic nodular cast iron was presented. The effect of an annealing temperature on hardness, impact strength and the microhardness of ausferritic nodular cast iron matrix was shown too. The lamellar structure of phases in the cast iron matrix after annealing has been ascertained. There has been an increase in hardness of an annealed cast iron and microhardness of its matrix. The reduction in the impact strength of the cast iron annealed at 520 and $550^{\circ} \mathrm{C}$ was approximately $10-30 \%$. Both an increase in the hardness of cast iron as well as an decrease in its impact strength is probably due to the separation of secondary carbides during the heat treatment.
\end{abstract}

Keywords: Innovative casting materials and technologies, Ausferritic nodular cat iron, Impact strength, Annealing

\section{Introduction}

Nodular cast iron is a material very often used by designers in many industries. Products made of this type of material are characterized by less weight compared to steel forgings and excellent mechanical properties with satisfactory casting properties [1]. World production of nodular cast iron castings was 25.7 million tons in 2014 and has increased since 2009 [2]. For many years the high-strength kinds of nodular cast iron enjoy especially great interest. The typical representative of highstrength cast iron is ADI covered by PN-EN 1564: 2012. Its high strength properties resulting from heat treatment of castings consisting in austempering [3-8]. As a result of this treatment an ausferrite is obtained in the matrix of the nodular cast iron. It is a mixture of high carbon austenite and bainitic ferrite. It provides excellent mechanical properties $\left(R_{m}\right.$ to $\left.1600 \mathrm{MPa}\right)$ with satisfactory elongation. Ausferritic microstructure can be obtained even without the use of heat treatment of castings (in a raw state) by an appropriate combination of alloying elements [9-11]. Further increasing in the adhesive and abrasive wear resistance of an ausferritic cast iron can be obtained by formation of carbides in its matrix (CADI - Carbidic Austempered Ductile Iron), or formation of the surface layer, e.g. nitrided. The preliminary data on the possibility of carrying out of nitriding of the ausferritic nodular iron are presented in paper [15]. This article is a continuation of it, and it concerns the effect of annealing temperature on the microstructure, hardness and impact strength of the ausferritic nodular cast iron. The choice of the annealing 
temperature was dictated by the temperature range used during nitriding.

\section{Test methodology}

Cast iron to the tests was melted in an induction furnace medium frequency crucible with a capacity of $30 \mathrm{~kg}$. The charge into the furnace was composed of a special pig iron, ferrosilicon FeSi75 and technically pure molybdenum and copper. The chemical composition of tested cast iron is given in Table 1. The nodulation and inoculation of the cast iron were performed by the Inmold process. Pouring temperature was $1480^{\circ} \mathrm{C}$. In the gating system of mould the reaction chamber was located. It had got a shape of a sphere with a diameter $\varphi 85 \mathrm{~mm}$. Inside this chamber the magnesium master alloy Lamet ${ }^{\circledR} 5504$ by Elkem was placed. Its composition is shown in Table 2. Test castings had got the shape of bar with square cross section of side $15 \mathrm{~mm}$. From these casts the specimens to metallographic and impact properties tests were cut out. Their shape was conforming to PN-EN ISO 1481:2010. Impact test was carried out on the Charpy impact test stand with using U-notch specimens and the initial machine energy $300 \mathrm{~J}$.

Table 1.

The chemical composition of tested cast iron

\begin{tabular}{cccccc}
\hline \multirow{2}{*}{ No. } & \multicolumn{5}{c}{ Chemical composition, \% mass. } \\
\cline { 2 - 6 } & $\mathrm{C}$ & $\mathrm{Si}$ & $\mathrm{Mn}$ & $\mathrm{Mo}$ & $\mathrm{Cu}$ \\
\hline 1. & 3.79 & 2.19 & 0.06 & 1.44 & 1.94 \\
\hline 2. & 4.16 & 2.02 & 0.05 & 1.77 & 2.51 \\
\hline
\end{tabular}

Table 2.

The chemical composition of master alloy

\begin{tabular}{cccccc}
\hline \multicolumn{6}{c}{ Chemical composition, \% mass. } \\
\hline $\mathrm{Si}$ & $\mathrm{Mg}$ & $\mathrm{Ca}$ & $\mathrm{La}$ & $\mathrm{Al}$ & $\mathrm{Fe}$ \\
\hline $44-48$ & $5-6$ & $0.4-0.6$ & $0.25-0.40$ & $0.8-1.2$ & et al. \\
\hline
\end{tabular}

The maximum concentration of sulfur was $0.02 \%$, and $0.05 \%$ phosphorus.

Annealing was carried out in a chamber resistance furnace by Neoterm company. There were used an annealing temperature 520 and $550^{\circ} \mathrm{C}$. The specimens were annealed for $8 \mathrm{~h}$. This choice was dictated by the temperatures used in the practice of nitriding and research contained in [15].

Metallographic examinations were carried out with using an optical microscope Eclipse MA200 by Nikon at a magnification of $\times 500$. The hardness of the cast iron was examined with using HPO-2400 hardness tester for the conditions: 187.5/2.5/30. Microhardness testing was performed on HV-1000B microhardness tester with a load of $0.9807 \mathrm{~N}$ in accordance with DIN EN ISO 6507-1. Due to the small dimensions of bainitic ferrite plates and austenite, the average microhardness of the aforementioned phases mixture was examined.

Fracture pictures of tested cast iron were made using scanning electron microscope S-3000N by Hitachi at a magnification of $\times 1500$.

\section{Results}

In Figure $1(\mathrm{a}, \mathrm{b})$ the microstructure of the not annealed ausferritic nodular cast iron is presented.

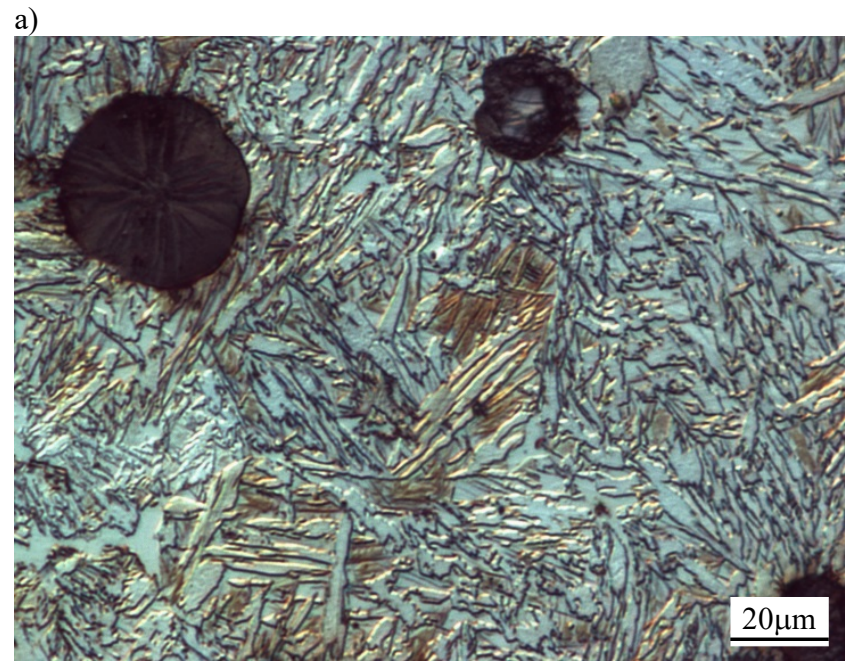

microstructure: nodular graphite, ausferrite

b)

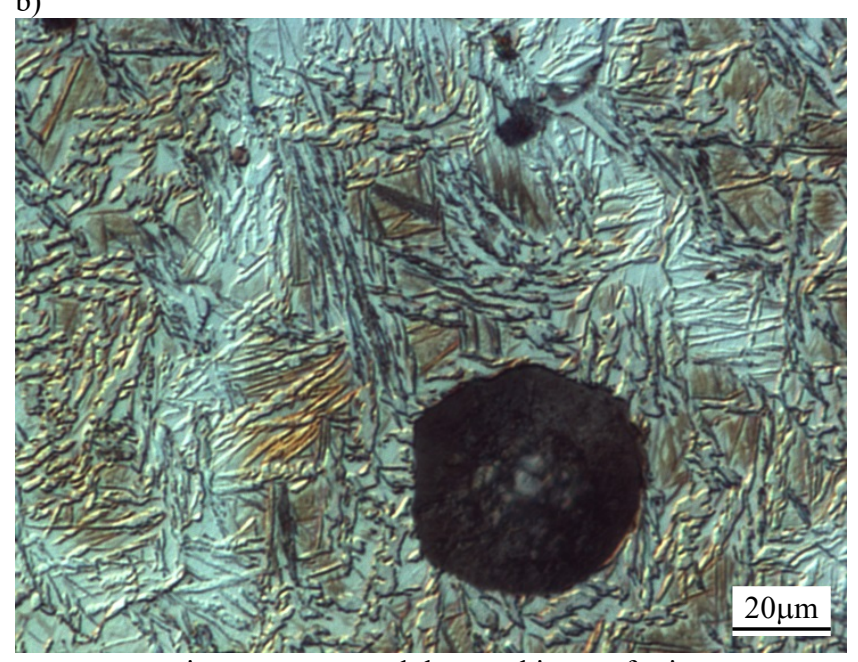

microstructure: nodular graphite, ausferrite

Fig. $1(\mathrm{a}, \mathrm{b})$. Microstructure of the not annealed ausferritic nodular cast iron containing about: a) $1.4 \% \mathrm{Mo}$ and $2.0 \% \mathrm{Cu}$, b) $1.8 \% \mathrm{Mo}$ and $2.5 \% \mathrm{Cu}$

Fig. 1a shows that there is the possibility of ausferrite obtaining in nodular cast iron containing about $1.5 \%$ Mo and $1.9 \% \mathrm{Cu}$, when castings are chilling in the mould. The increase in copper concentration of about $2.5 \%$ results in increase in fraction of the plates at a regular shape characteristic for the lower ausferrite (Fig. 1b). The lower ausferrite is the mixture of bainitic ferrite plates and austenite. The plates of bainitic ferrite in the lower ausferrite have a shape similar to plates in a lower bainite in steels. The lower ausferrite is usually obtained with use of 
austempering (austenitizing and as a next quenching at the temperature range $\sim 250-400^{\circ} \mathrm{C}$ ) [1].

The microstructure of nodular cast iron containing approximately $1.5 \% \mathrm{Mo}$ and $1.9 \% \mathrm{Cu}$ after annealing at $520^{\circ} \mathrm{C}$ is shown in Figure $2(a, b)$.

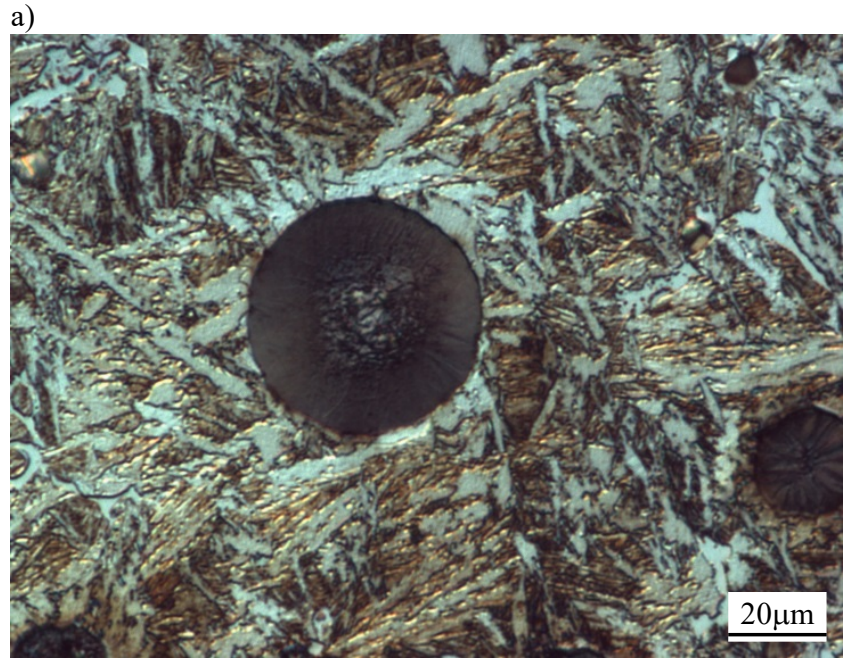

b)

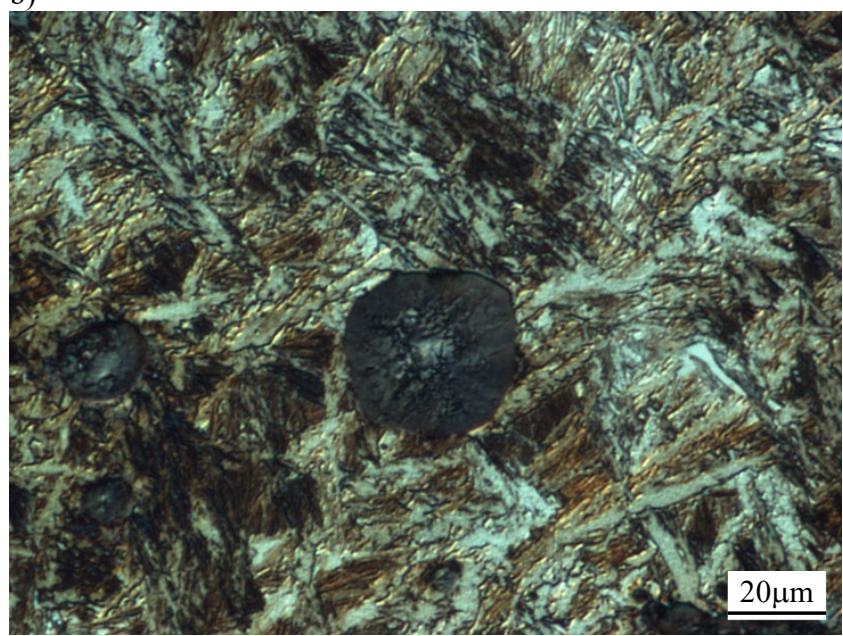

Fig. 2 (a, b). The microstructure of ausferritic nodular cast iron containing about: a) $1.4 \% \mathrm{Mo}$ and $2.0 \% \mathrm{Cu}$, b) $1.8 \% \mathrm{Mo}$ and

$2.5 \% \mathrm{Cu}$ after annealing at the temperature of $520^{\circ} \mathrm{C}$

From Fig. 2 it shows the ausferritic nodular cast iron matrix after annealing at $520^{\circ} \mathrm{C}$ is characterized by a acicular morphology. This is probably due to incomplete transformation of austenite after annealing, as it has been demonstrated in paper [15].

In Figure $3(\mathrm{a}, \mathrm{b})$ the microstructure of the ausferritic nodular cast iron containing about $1.4 \% \mathrm{Mo}$ and $1.9 \% \mathrm{Cu}$ (a) and $1.8 \%$ $\mathrm{Mo}$ and $2.0 \% \mathrm{Cu}$ annealed at the temperature of $550^{\circ} \mathrm{C}$ is presented.

a)

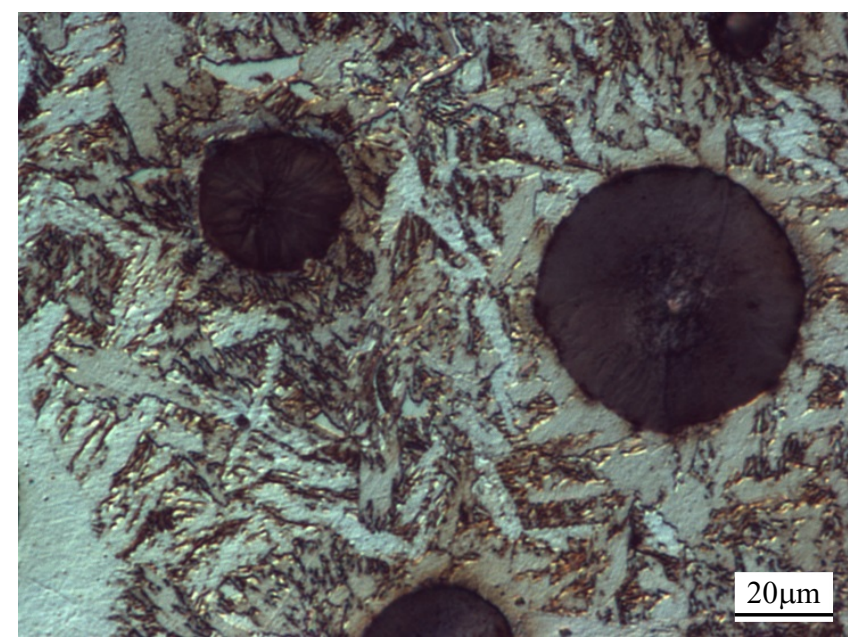

b)

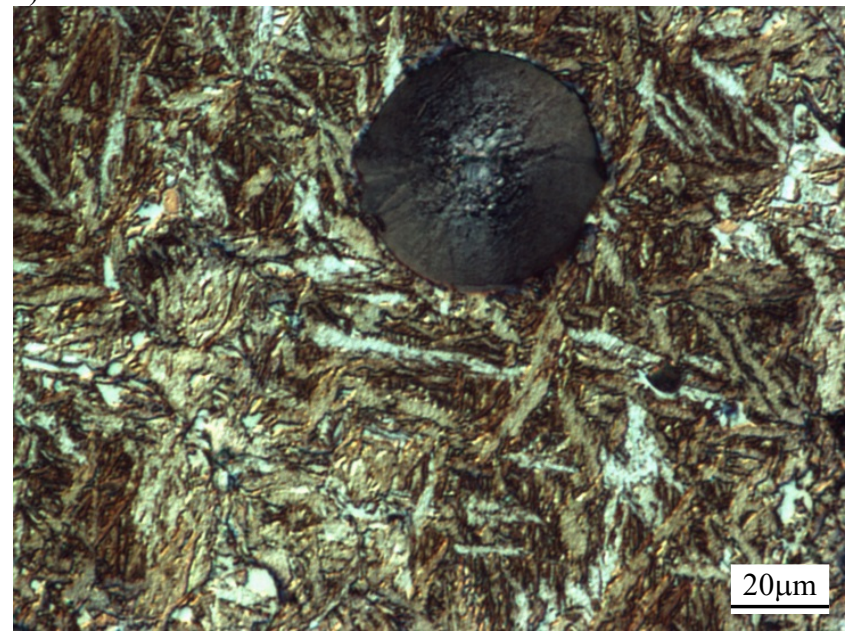

Fig. $3(a, b)$. The microstructure of ausferritic nodular cast iron containing about: a) $1,5 \%$ Mo and $2 \% \mathrm{Cu}$, b) $1,5 \%$ Mo and $2,5 \%$ $\mathrm{Cu}$ after annealing in $550^{\circ} \mathrm{C}$

It shows from Fig. 3 that the increase in the annealing temperature does not cause the significant changes in the matrix of nodular cast iron. The structure of the phases constituting the matrix is still lamellar.

Effect of the annealing temperature and the chemical composition on the microhardness of the ausferritic nodular cast iron matrix is shown in Table 3. 
Table 3.

Matrix microhardness of ausferritic nodular cast iron

\begin{tabular}{|c|c|c|c|c|}
\hline \multirow{2}{*}{ No. - } & Mo & $\mathrm{Cu}$ & \multirow{2}{*}{\multicolumn{2}{|c|}{$\begin{array}{c}\text { Annealing temperature, Matrix microhardness, } \\
{ }^{\circ} \mathrm{C}\end{array}$}} \\
\hline & \multicolumn{2}{|c|}{$\%$ mass. } & & \\
\hline \multirow{3}{*}{1} & \multirow{3}{*}{1.4} & \multirow{3}{*}{1.9} & not annealed & 222.8 \\
\hline & & & 520 & 256.0 \\
\hline & & & 550 & 273.7 \\
\hline \multirow{3}{*}{2} & \multirow{3}{*}{1.8} & \multirow{3}{*}{2.5} & not annealed & 272.3 \\
\hline & & & 520 & 281.5 \\
\hline & & & 550 & 296.8 \\
\hline
\end{tabular}

It results from Tab. 3 the matrix microhardness of the non annealed cast iron No. 1 is higher than the No. 2. This is due to the higher concentrations of $\mathrm{Mo}$ and $\mathrm{Cu}$, resulting in a larger amount of the lower ausferrite.

The annealing resulted in an increase in the matrix microhardness of the ausferritic nodular cast iron both after annealing at 520 and $550^{\circ} \mathrm{C}$. The increase amounted to about 50 $\mathrm{HV}$ for cast iron containing 1.4\% Mo and 1.9\% Cu (No. 1) and about $24 \mathrm{HV}$ for the cast iron containing $1.8 \% \mathrm{Mo}$ and $2.0 \% \mathrm{Cu}$ (No. 2). This increase is probably caused by the separation of secondary carbides.

The effect of an annealing temperature on the hardness of an ausferritic nodular cast iron is shown in Table 4 .

Table 4.

Hardness of the ausferritic nodular cast iron

\begin{tabular}{|c|c|c|c|c|}
\hline \multirow{2}{*}{ No. } & Mo & $\mathrm{Cu}$ & \multirow{2}{*}{$\begin{array}{l}\text { Annealing temperature, } \\
{ }^{\circ} \mathrm{C}\end{array}$} & \multirow{2}{*}{ HB hardness } \\
\hline & & & & \\
\hline \multirow{3}{*}{1} & \multirow{3}{*}{1.4} & \multirow{3}{*}{1.9} & not annealed & 395.8 \\
\hline & & & 520 & 400.2 \\
\hline & & & 550 & 414.0 \\
\hline \multirow{3}{*}{2} & \multirow{3}{*}{1.8} & \multirow{3}{*}{2.5} & not annealed & 371.4 \\
\hline & & & 520 & 418.8 \\
\hline & & & 550 & 410.8 \\
\hline
\end{tabular}

It results from Tab. 4 the annealing of the ausferritic nodular cast iron causes the increase its hardness. For the cast iron No. 1 an increase in annealing temperature resulting in an increase in hardness, whereas for the cast iron No. 2 the highest hardness was obtained for the cast iron annealed at $520^{\circ} \mathrm{C}$.

In Figure 4 (a-c) fractures of cast iron No. 1: a) not annealed, b) annealed at $520^{\circ} \mathrm{C} \mathrm{c}$ ) annealed at $550^{\circ} \mathrm{C}$ are presented, while Figure 5 (a-c) presents fractures of cast iron No. 2: a) not annealed, b) annealed at $520^{\circ} \mathrm{C} \mathrm{c}$ ) annealed at $550^{\circ} \mathrm{C}$. a)

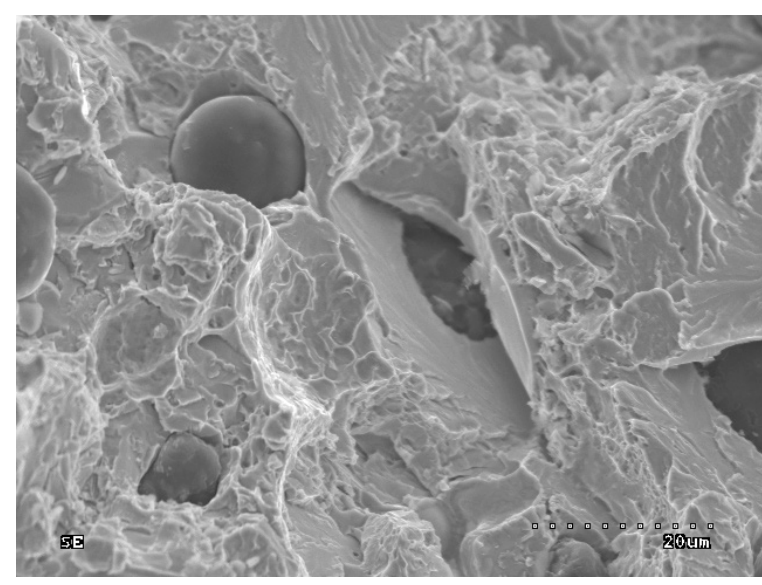

b)

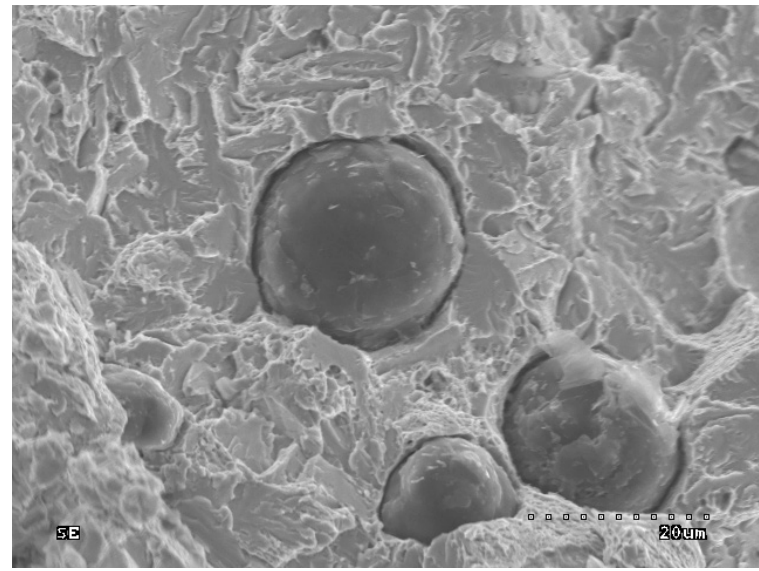

c)

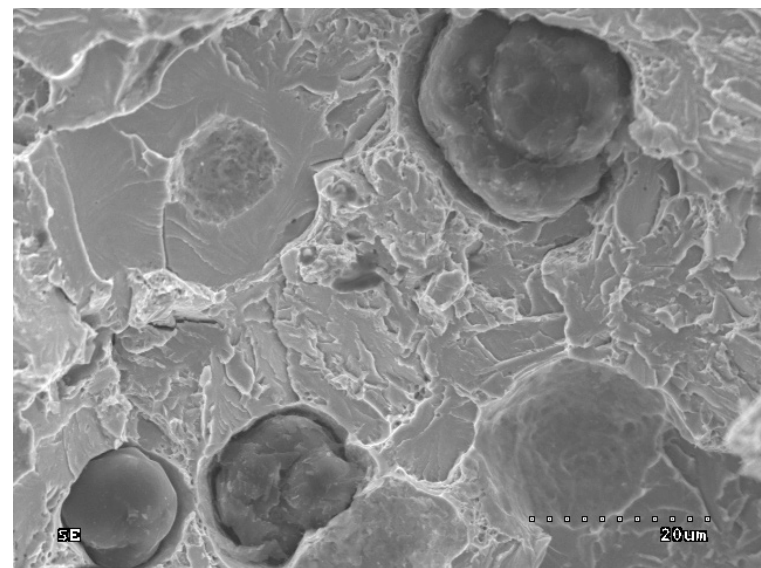

Fig. 4 (a-c). Fracture of an ausferritic nodular cast iron containing about $1.4 \%$ Mo and $1.9 \% \mathrm{Cu}$ : a) not annealed, b) annealed at $520^{\circ} \mathrm{C}, \mathrm{c}$ ) annealed at $550^{\circ} \mathrm{C}$ 
a)

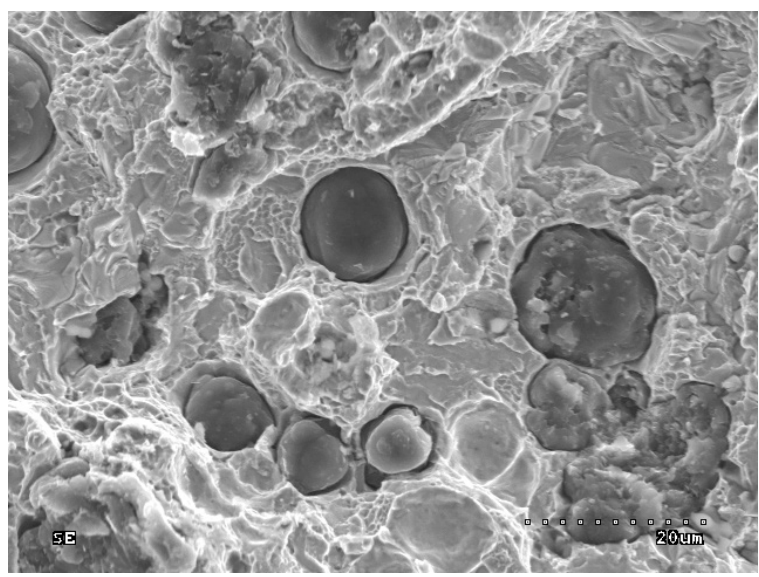

b)

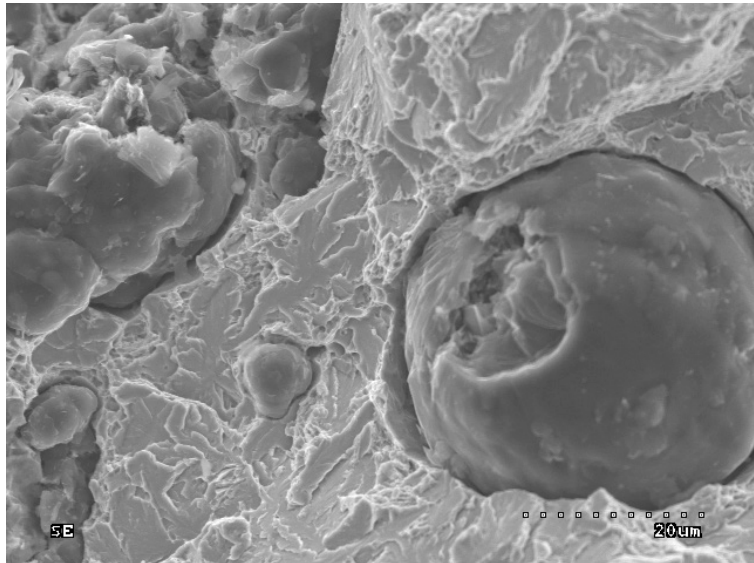

c)

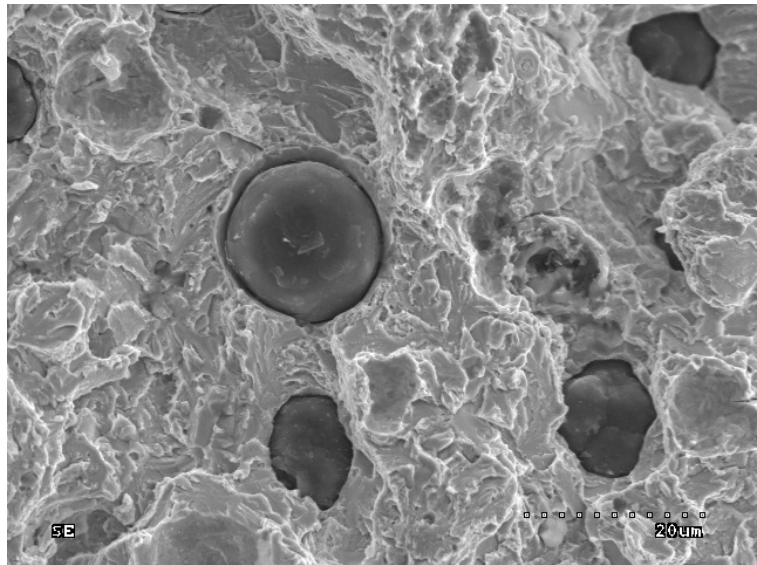

Fig. 5 (a-c). Fracture of an ausferritic nodular cast iron containing about $1.8 \% \mathrm{Mo}$ and $2.5 \% \mathrm{Cu}$ : a) not annealed,

b) annealed at $520^{\circ} \mathrm{C}, \mathrm{c}$ ) annealed at $550^{\circ} \mathrm{C}$

It shows from Figs. 4a and 5a the fracture of the not annealed ausferritic nodular cast iron demonstrates features of both brittle and ductile fracture, with a predominance of the first one. The annealing of cast iron caused a decrease in the ductile fracture
(Fig. $4 \mathrm{~b}, \mathrm{c}$ and $5 \mathrm{~b}, \mathrm{c}$ ). The ductile fracture decreased with an increasing the annealing temperature.

Table 5 shows the results of the impact strength test of the ausferritic nodular cast iron.

Table 5.

Impact strength of ausferritic nodular cast iron

\begin{tabular}{|c|c|c|c|c|}
\hline \multirow{2}{*}{ No. } & Mo & $\mathrm{Cu}$ & \multirow{2}{*}{$\begin{array}{c}\text { Annealing temperature, } \\
{ }^{\circ} \mathrm{C}\end{array}$} & \multirow{2}{*}{$\begin{array}{c}\text { Impact strength, } \\
\mathrm{J}\end{array}$} \\
\hline & & & & \\
\hline \multirow{3}{*}{1} & \multirow{3}{*}{1.4} & \multirow{3}{*}{1.9} & not annealed & 7.7 \\
\hline & & & 520 & 6.3 \\
\hline & & & 550 & 5.3 \\
\hline \multirow{3}{*}{2} & \multirow{3}{*}{1.8} & \multirow{3}{*}{2.5} & not annealed & 7.2 \\
\hline & & & 520 & 6.9 \\
\hline & & & 550 & 6.5 \\
\hline
\end{tabular}

It results from Tab. 5 the annealing of the ausferritic nodular cast iron No. 1 caused a decrease in the impact strength of approximately $30 \%$, while cast iron No. 2 by about $10 \%$.

\section{Conclusions}

The results of the research predestine to the following conclusions:

- the annealing of ausferritic nodular cast iron in the temperature $520-550^{\circ} \mathrm{C}$ results in reducing the ductile fracture, probably due to the separation of secondary carbides during the heat treatment,

- the annealing of ausferritic nodular cast iron in the temperature $520-550^{\circ} \mathrm{C}$ results in an increases both the hardness and matrix microhardness,

- the impact strength of ausferritic nodular cast iron annealed at $520-550^{\circ} \mathrm{C}$ is reduced by approximately $10-30 \%$.

\section{References}

[1] Guzik, E. (2001). Some Selected Problems Concerning the Processes of Cast Iron Improvement. Monograph, 1M. Katowice: Archives of Foundry. (in Polish).

[2] 49th Census of World Casting Production, Retrieved February 25, 2016, from http://www.foundryinfoindia. org/statis-tics/Dec15\%20Census.pdf.

[3] Guzik, E., Kapturkiewicz, W., Lelito, J. (2000). Principles of obtaining ausferritic cast iron. International Scientific Conference on ADI cast iron - offer of casting for constructors and cast users. Kraków, 23-24.IX.2000, I/11.

[4] Tybulczuk, J., Kowalski, A.W. (2003). ADI cast iron properties and application in industry. Casts Atlas. Kraków: Foundry Institute. (in Polish).

[5] Keough, J.R. (2012). Austempered Ductile Iron (ADI) - A Green Alternative, Applied Process Inc., April 2010, Retrieved March 07, 2016, from http://www.appliedprocess.com/Custom/Document/GetFile/ab6da2d6-8675437a-8c82-f32361 edf768.

[6] Retrieved March 07, 2016, from http://www.keytometals.com/page.aspx?ID $=$ CheckArticle $\&$ site $=\mathrm{kts} \& \mathrm{NM}=243$. 
[7] Guzik, E. (2006). Selected issues on the structure and properties of ausferritic cast iron. Archives of Foundry. 6(21), 33-42. (in Polish).

[8] Guzik, E. (2010). Ausferritic cast iron and its forms structure and selected properties, Tendencies for Optimization of Production Systems in Foundries, Collective Work edited by Stanisław Pietrowski, Katowice - Gliwice. 105-110.

[9] Gumienny, G. (2013). Selected aspects of the theory and technology of the production of nodular cast iron with carbides obtained in the state as-cast, Scientific Journals No. 1140. Scientific Dissertations. Z. 440. Łódź: Publishing House of Lodz University of Technology. (in Polish).

[10] Gumienny, G. (2013). Carbidic Bainitic and Ausferritic Ductile Cast Iron. Archives of Metallurgy and Materials. 58(4), 1053-1058.

[11] Ferry, M. \& Xu, W. (2004). Microstructural and crystallographic features of ausferrite in as-cast gray iron.
Materials Characterization. 53(1), 43-49. DOI: 10.1016/j.matchar.2004-.07.008.

[12] Paczkowska, M. (2013). Possibility analysis of laser nitriding of nodular iron. Surface Engineering. 2. 75-77. (in Polish).

[13] Wang, N. \& Liu, J. (2013). Effect of Process Parameters on Gas Nitriding of Grey Cast Iron. Advances in Materials Science and Engineering. 2013,(Article ID 217848), 1-6. DOI:10.1155/2013/217848.

[14] Nicoletto, G., Konečná, R. Majerová, V. Fatigue Behavior and Fracture Mechanisms of Nitrided Nodular Cast Iron. Retrieved March 09, 2016, from http://www.gruppofrattra.it/ocs/index.php/esis/CP2006/paper/viewFile/9517/6140 access 20.05.2014.

[15] Gumienny, G. \& Klimek, L. (2014). Effect of Temperature on Ausferritic Nodular Cast Iron Microstructure. Archives of Foundry Engineering. 14(special 3), 21-24. 